DOI: $10.19195 / 0524-4544.328 .12$

\author{
JÓZEF KOREDCZUK \\ ORCID: 0000-0002-3471-586X \\ Uniwersytet Wrocławski \\ jozef.koredczuk@uwr.edu.pl
}

\title{
Dzieje Katedry Ekonomii Politycznej na Wydziale Prawa Uniwersytetu Wrocławskiego w latach 1945-1956
}

Niezbędność znajomości podstaw ekonomii przez osoby studiujące prawo uznawano już w okresie międzywojennym, stąd też na wydziałach prawa w ramach ich struktury tworzone były katedry ekonomii politycznej. Strukturę tę reaktywowano na nowo powstających wydziałach prawa polskich uniwersytetów po drugiej wojnie światowej, podobnie było na Wydziale Prawa Uniwersytetu Wrocławskiego. W spisach wykładów początkowo określano, że liczba godzin poszczególnych wykładów jest określona według ordynacji studiów z roku 1938. Od roku akademickiego 1947/1948 informowano już, że plan wykładów i zajęć obowiązkowych został określony na podstawie rozporządzenia Ministra Oświaty z dnia 31 października 1947 roku (nr IV SW-2216/46) ${ }^{1}$.

Pierwszą Katedrę Ekonomii Politycznej na Wydziale Prawa Uniwersytetu Wrocławskiego utworzono na podstawie zarządzenia Ministra Oświaty z dnia 30 kwietnia 1946 roku, jej kierownictwo objął prof. Wincenty Styś. Jednocześnie do życia powołano drugą Katedrę Ekonomii Politycznej do badania rynku kapitałowego i wielkich przedsiębiorstw, na razie póki co bez obsady personalnej. Sprawą jej obsady zajęto się na posiedzeniu Rady Wydziału w dniu 12 czerwca 1946 roku. W tym celu powołano na nim specjalną komisję, która miała przedstawić stosowne wnioski co do obsady. W jej skład weszli: dziekan Iwo Jaworski, jako przewodni-

1 Spis wykładów w roku akademickim 1945/46, Wrocław 1946, s. 29; Spis wykładów w roku akademickim 1947/8, Wrocław 1947, s. 27. 
czący, oraz profesorowie Adam Chełmoński, W. Styś, Tadeusz Bigo i Aleksander Całkosiński, jako członkowie. Do sprawy powrócono na Radzie Wydziału w dniu 31 marca 1947 roku, na której upoważniono dziekana I. Jaworskiego, by zwrócił się z zapytaniem do prof. Stanisława Świaniewicza (byłego profesora ekonomii Uniwersytetu Stefana Batorego w Wilnie) $)^{2}$, czy byłby chętny objąć wspomnianą kate$\mathrm{drę}^{3}$. Jako były polski sowietolog i jeden z nielicznych żyjących świadków zbrodni w Katyniu obawiał się on jednak przyjazdu do Polski. Na posiedzeniu Rady Wydziału 17 maja 1947 roku ponownie upoważniono powołaną komisję, by przygotowała materiały dotyczące obsady drugiej katedry ekonomii politycznej. Kolejna propozycja komisji, przedstawiona na posiedzeniu Rady Wydziału w dniu 15 lipca 1947 roku, polegająca na powierzeniu zastępstwa kierownictwa katedry dr. Wacławowi Skrzywanowi, została odrzucona. W tej sytuacji dziekan I. Jaworski w miejsce katedry ekonomii politycznej zaproponował utworzenie katedry ekonometryki ${ }^{4}$. Również ta propozycja nie spotkała się z przyjęciem Rady Wydziału, dlatego też tymczasowo na rok akademicki 1947/1948 zaproponowano powierzenie katedry dr. Stanisławowi Serwackiemu ${ }^{5}$. Ostatecznie wobec niemożności jej obsady została ona w 1949 roku zlikwidowana jako przedmiotowo nieprzydatna w gospodarce nakazowej, w której od prawników oczekiwano znajomości metod statystycznych, czym uzasadniano powołanie na Wydziale jeszcze w tym samym roku Katedry Statystyki, której kierownictwo objął W. Skrzywan ${ }^{6}$.

Pozostała zatem tylko pierwsza Katedra Ekonomii Politycznej, której zakres obejmował teorię ekonomii i funkcjonowanie gospodarki rynkowej, współcześnie określanej jako ekonomia klasyczna i neoklasyczna. Początkowo jej zespół tworzyli byli pracownicy Katedry Ekonomii Społecznej ze Lwowa, kierowanej przez Stanisława Grabskiego, brata Władysława Grabskiego, twórcy reformy walutowej w 1924 roku. Oprócz W. Stysia należeli do niej dr S. Serwacki oraz Zygmunt Banaszewski (asystent) ${ }^{7}$.

${ }^{2}$ Iwo Jaworski znał prof. S. Świaniewicza jeszcze z czasów wileńskich. Profesor Świaniewicz, który przebywał w Wielkiej Brytanii, nie zdecydował się jednak na przyjazd do Wrocławia.

3 Archiwum Uniwersytetu Wrocławskiego, Wydział Prawno-Administracyjny W-III/0001, Rada Wydziału — protokoły posiedzeń 1946-1949, sygn. AU-271/1, s. 10, 51.

4 Ekonometria - nauka pomocnicza ekonomii, wykorzystująca narzędzia matematyki, statystyki oraz współcześnie informatyki do badania ilościowych związków zachodzących między zjawiskami i zmiennymi ekonomicznymi. Nie należy jej mylić ze statystyką.

5 Archiwum Uniwersytetu Wrocławskiego, Wydział Prawno-Administracyjny W-III/0001, Rada Wydziału — protokoły posiedzeń 1946-1949, sygn. AU-271/1, s. 62, 70-72.

6 E. Kundera, Instytut Nauk Ekonomicznych, „Przegląd Prawa i Administracji” 100/1, 2015, s. 329; J. Koredczuk, Stowo wstepne, [w:] Wydział Prawa, Administracji i Ekonomii Uniwersytetu Wrocławskiego w fotografiach (1945-2010), oprac. L. Lehmann, Wrocław 2010, s. 10.

7 E. Kundera, Instytut Nauk Ekonomicznych, s. 329. Z. Banaszewski nie był byłym pracownikiem Katedry Ekonomii Społecznej we Lwowie, lecz Katedry Ekonomii Politycznej na Uniwersytecie Jagiellońskim, na którym w 1945 roku pod kierunkiem prof. Adama Krzyżanowskiego obronił doktorat pt. Agrarne gospodarstwo Polski na tle światowej sytuacji gospodarczej; A.K., Adw. dr Zygmunt Banaszewski [wspomnienia pośmiertne], „Palestra” 31, 1987, nr 6, s. 83.

Prawo 328, 2019

(C) for this edition by CNS 
Tę początkowo skromną kadrę Katedry z czasem stopniowo powiększono, zatrudniając przede wszystkim pomocniczych pracowników nauki. Od roku akademickiego 1948/1949 ćwiczenia zaczęli prowadzić — oprócz jedynego dotychczas asystenta Z. Banaszewskiego — starsi asystenci magistrowie Witold Ancuta, Stanisław Walczak i Jan Nadwyczański oraz jako wolantariusze Krzysztof Jeżowski i Edmund Piasecki ${ }^{8}$. Natomiast według źródeł archiwalnych J. Nadwyczański został starszym asystentem w grudniu 1946 roku, obejmując etat po Wiktorze Skubiejewskim, który nie podjął obowiązków asystenckich ${ }^{9}$.

By otrzymać stały etat asystenta, kandydaci najczęściej przez jakiś czas byli asystentami wolonturiuszami przy katedrze. Tak było w przypadku W. Ancuty, który najpierw od listopada 1946 roku był asystentem wolontariuszem przy Katedrze Ekonomii Politycznej, a dopiero potem został zatrudniony na stałe. Również K. Jeżowski i E. Piasecki zostali asystentami wolontariuszami nie od roku akademickiego 1948/1949, jak podano w Spisie wykładów (opublikowany został on przed ich powołaniem przez Radę Wydziału na asystentów wolontariuszy), lecz E. Piasecki od 25 września 1947 roku, a K. Jeżowski od 27 października 1947 roku. Asystentem wolontariuszem zaś przy Katedrze od 12 stycznia 1949 roku był student czwartego roku studiów Józef Popkiewicz. Natomiast odmową przez ministerstwo zakończyła się próba zatrudnienia na pół etatu jako asystent wolontariusz studentki czwartego roku Jolanty Kozłowskiej. Zapewne na jej miejsce w kwietniu 1949 roku prof. W. Styś zaproponował zatrudnienie na pół etatu Janusza Fraszczyka ${ }^{10}$.

Od 1 września 1951 roku jako asystentów zatrudniono Frydę Kamerling i Józefa Rembiasza. Duże zmiany personalne zaszły w Katedrze w 1953 roku. Od 1 stycznia 1953 roku zatrudniono asystentów: Tomasza Afeltowicza ${ }^{11}$ oraz Michała Dobroczyńskiego, a półtora miesiąca po nich Alfreda Klicha ${ }^{12}$. Adam Bielecki zaś i Karol Gandor otrzymali angaż od 1 września 1953 roku $^{13}$. Na stanowisko adiunkta w 1953 roku przyjęto także Rafała Sorgensteina ${ }^{14}$. Ostatnia w analizowanym okresie została zatrudniona asystentka Ambrozikowa.

Oceniający w 1957 roku sytuację kadrową W. Styś stwierdził: „Po okresie nienormalnych warunków, w jakich znalazł się nasz Wydział w ostatnich latach, jest niemożliwe, by »właściwy człowiek był na właściwym miejscu«"15.

8 Spis wykładów w roku akademickim 1948/9, Wrocław 1948, s. 20-21.

9 Archiwum Uniwersytetu Wrocławskiego, Wydział Prawno-Administracyjny W-III/0001, Rada Wydziału — protokoły posiedzeń 1946-1949, sygn. AU-271/1, s. 34.

10 Ibidem, s. 29, 74, 79, 91, 105, 112.

11 L. Olszewski, Droga życiowa, „Ekonomia” 2018, nr 18, s. 13.

12 Archiwum Uniwersytetu Wrocławskiego, W-VIII-52, Zespoły katedr i instytutów 19501975 (karty nienumerowane).

13 Przewodniczący uczelnianej organizacji ZMP, który po październiku 1956 roku, przeniósł się do Katedry Prawa Cywilnego; Archiwum Uniwersytetu Wrocławskiego, Wydział Prawa W-III/0001, Rada Wydziału — protokoły posiedzeń 1956-1960, sygn. AU-271/3, s. 333.

14 Mimo że studia ekonomiczne w Szkole Głównej Planowania i Statystyki w Warszawie ukończył dopiero w 1954 roku.

15 W. Wrzesiński, Uniwersytet Wrocławski 1945-1995, Wrocław 1995, s. 186-187. 
Zgodnie z programem Katedry przedmiotem jej działalności naukowo-dydaktycznej miała być ekonomia polityczna, z której wykłady były też czasami określane tylko z samej ekonomii (bez politycznej) ${ }^{16}$ oraz powiązanej z nią historii doktryn ekonomicznych i historii gospodarczej. Oprócz wykładów z tych przedmiotów, prowadzonych na ogół przez W. Stysia bądź S. Serwackiego - zastępcę profesora, były także ćwiczenia, prowadzone przez pomocniczych pracowników nauki. $Z$ ekonomii politycznej prowadzone było także seminarium.

W ramach specjalizacji, która pojawiała się na studiach od trzeciego roku, wykładano dodatkowe przedmioty ekonomiczne. Na specjalizacji administracyjnej w roku akademickim 1947/1948 była to ekonomia jednostkowa, prowadzona przez dr. Józefa Lisaka (dyrektora Studium Gospodarczo-Społecznego w Katowicach $)^{17}$. W roku akademickim 1948/1949 przedmiot ten także wykładano na specjalizacji skarbowej. Oprócz ekonomii jednostkowej na specjalizacji administracyjnej (na IV roku) pojawił się przedmiot organizacja przemysłu państwowego, prowadzony przez K. Jeżowskiego ${ }^{18}$.

W roku akademickim 1949/1950 wykład z historii doktryn gospodarczych prowadzony był z oratorską brawurą — jak wspomina prof. Tadeusz Kuta przez W. Stysia. I mimo że z wykładów tych w zderzeniu ze słabo jeszcze rozwiniętą, ale obowiązującą politycznie - marksistowską doktryną ekonomii politycznej wyszedł on zwycięsko, to jednak musiał przegrać ostatecznie, albowiem wykład ten przekształcono w nadobowiązkowy ${ }^{19}$. Pojawiły się także w programie trzeciego roku studiów dwa nowe wykłady nadobowiązkowe: zagadnienia statystyczne planu gospodarczego oraz badania powszechne i reprezentacyjne w naukach społecznych, prowadzone przez W. Skrzywana ${ }^{20}$.

Początkowa wolność nauki i nauczania na uczelniach polskich nie trwała długo, zakończyła się wraz ze zmianami dokonanymi w Polsce w 1948 roku. Po 1948

16 Wykłady i ćwiczenia zlecone z ekonomii w roku akademickim 1947/1948, prowadzone przez dr. S. Serwackiego były opłacone z niewykorzystanych funduszy przeznaczonych na utworzenie drugiej katedry ekonomii politycznej; Archiwum Uniwersytetu Wrocławskiego, Wydział Prawno-Administracyjny W-III/0001, Rada Wydziału — protokoły posiedzeń 1946-1949, sygn. AU-271/1, s. 61.

17 Spis wykładów w roku akademickim 1947/8, s. 25. Przed wojną opublikował on monografię naukową o podobnym tytule - Ekonomia jednostkowa. Nauka o przedsiębiorstwie (Katowice 1939). Warto zaznaczyć, że w 1945 dr J. Lisak, licząc na poparcie gen. Aleksandra Zawadzkiego, podjął wiele niekorzystnych decyzji dla przyszłości Uniwersytetu we Wrocławiu. Między innymi usiłował studium, którym kierował, przekształcić w uniwersytet. Zabiegał też, aby Katowicom przekazano poniemiecki majątek Uniwersytetu we Wrocławiu. Starał się bezskutecznie o włączenie do grupy Stanisława Kulczyńskiego. Na szczęście nic z tych planów J. Lisaka nie wyszło; W. Wrzesiński, op. cit., s. 15.

18 Spis wykładów w roku akademickim 1948/9, s. 24, 26.

19 T. Kuta, Moje wspomnienia, „Studia i Materiały z Dziejów Uniwersytetu Wrocławskiego” 2, 1993, s. 243.

20 Spis wykładów w roku akademickim 1949/50, Wrocław 1949, s. 29, 31. 
roku nauka i szkolnictwo wyższe stały się celem generalnym ataku partii, a wolność nauki i nauczania zostały wyparte przez marksizm i leninizm ${ }^{21}$.

W marcu 1950 roku w ramach socjalistycznych reform szkolnictwa wyższego w miejsce katedr planowano utworzenie instytutów. Na Wydziale Prawa Uniwersytetu Wrocławskiego planowany instytut ekonomiczny miał obejmować dwie katedry ekonomii (pierwszą i drugą), katedrę skarbowości oraz katedrę spółdzielczości. Wcześniejsze plany przewidywały także zaproszenie do wejścia w jego skład katedry historii gospodarczej na Wydziale Humanistycznym oraz katedry ekonomii rolnej na Wydziale Rolniczym. Poza strukturą planowanego instytutu miała pozostać katedra statystyki, której sprawa przyłączenia do instytutu budziła wątpliwości. W lipcu 1950 roku pojawiła się nowa koncepcja organizacji Wydziału. Zgodnie z projektem przygotowanym przez prodziekana A. Chełmońskiego przewidywano utworzenie zespołu katedr ekonomicznych i spółdzielczości ${ }^{22}$.

W Katedrze jednak coraz bardziej nie było miejsca na taką ekonomię, jak ją rozumiał W. Styś, że jest „to zdrowy rozsądek podany w trudnej formie”23. Już w 1948 roku naraził się on decydentom politycznym, proponując tworzenie w Polsce spółdzielni mechanizacyjnych, co było sprzeczne z założeniami marksizmu i mającej się wkrótce rozpocząć kolektywizacji wsi. Dlatego od 1950 roku był on jako „człowiek ideologicznie obcy” objęty rozpracowaniem przez służby bezpieczeństwa w ramach sprawy o kryptonimie „Wschód”24.

Stopniowe eliminowanie W. Stysia rozpoczęło się najpierw od zakazania mu w 1949 roku wykładania ekonomii politycznej — za propagowanie na wykładach ekonomii burżuazyjnej ${ }^{25} \mathrm{i}$,absolutną nieznajomość marksizmu”. Pozostał mu jedynie wykład z historii gospodarczej powszechnej, który natomiast został przekształcony w nadbowiązkowy i na który uczęszczało coraz mniej studentów. Próbując ratować W. Stysia, na posiedzeniu Rady Wydziału dnia 20 marca 1952 roku Seweryn Wysłouch zaproponował jego przejście do Katedry Historii Państwa i Prawa Polskiego, uzasadniając to jego dotychczasową pracą badawczą ${ }^{26}$. Propozycje S. Wysłoucha rozpatrywano na posiedzeniu Rady w dniu 11 września 1952 roku. Swój wcześniejszy wniosek S. Wysłouch uzasadniał dodatkowo potrzebami badawczymi Katedry Historii Państwa i Prawa Polskiego, która była jedynym ośrod-

21 E. Kundera, Instytut Nauk Ekonomicznych, s. 329.

22 Archiwum Uniwersytetu Wrocławskiego, Wydział Prawa (W. Prawno-Administracyjny do 1950 r.) W-III/0001, Rada Wydziału — protokoły posiedzeń 1950-1956, sygn. AU-271/2, s. 7, 11, 46.

23 Cyt. za: F. Ryszka, Pamiętnik inteligenta. Samo życie, Łódź 1996, s. 47.

24 J.R. Sielezin, Działania UB wobec kadry naukowej Uniwersytetu Wrocławskiego w 1950 roku, „Śląski Kwartalnik Historyczny Sobótka” 63, 2008, nr 1, s. 40.

25 Znana jest sytuacja, kiedy prof. W. Styś na wykładzie dowodził, że „cegła wyprodukowana w prywatnych cegielniach jest znacznie lepsza i bardziej poszukiwana na rynku, niż cegła wyprodukowana przez cegielnie państwowe, bo przecież to współzawodnictwo, to przekraczanie planów... to wszystko osłabia jakość cegły", ibidem, s. 47.

26 J. Koredczuk, 60-lecie powołania katedr historyczno-prawnych na Wydziale Prawa Uniwersytetu Wrocławskiego, „Prawo” 303, 2007, s. 15. 
kiem w Polsce specjalizującym się w historii okresu kapitalistycznego i odczuwała dotkliwy brak ekonomisty ${ }^{27}$. Mimo jednogłośnej uchwały Rady Wydziału Prawa w sprawie przedmiotowego wniosku ostatecznie w 1953 roku W. Styś został przeniesiony na Wydział Filozoficzno-Historyczny do Katedry Historii Gospodarczej i wykładał tam historię myśli ekonomicznej i historię gospodarczą ${ }^{28}$. Zajmująca się jego sprawą specjalnie powołana komisja w składzie: Józef Fiema, Stefan Inglot ${ }^{29}$ i J. Popkiewicz ${ }^{30}$, doszła do wniosku, że jego działalność naukowa nie uzasadnia celowości pozostawania go na Wydziale Prawa ${ }^{31}$. Uważała ona natomiast, że jego wiedza ekonomiczna, a zwłaszcza znajomość historii gospodarczej Niemiec w epoce kapitalizmu mogłyby oddać duże usługi zespołowi historyków, mających pracować nad najnowszymi dziejami Śląska ${ }^{32}$. I sami chyba w to nie wierząc, ale na potrzeby ministerstwa, członkowie wspomnianej komisji stwierdzili, że

Pomimo podnoszonych zarzutów metodologicznych i niesprecyzowanego dotąd stanowiska prof. Stysia do niektórych założeń marksistowskiej ekonomii politycznej, z uwagi na stałe pogłębianie marksistowskiej ekonomii politycznej — Komisja uważa, iż należy przypuszczać, że prof. Styś otoczony właściwą opieką ideologiczno-polityczną, której dotychczas nie potrafiono mu zapewnić, stanie się pożytecznym pracownikiem naukowym w Katedrze Historii Polski ${ }^{33}$.

Członkowie komisji tylko pozornie byli nieżyczliwi prof. W. Stysiowi. W rzeczywistości potępili i skrytykowali go oni po to, by uratować przed znacznie gorszymi represjami, które mogły spotkać prof. W. Stysia ze strony władz. Opinia ich o nim prawdopodobnie była przygotowana i zaakceptowana przez samego prof. W. Stysia ${ }^{34}$.

Kłopoty mieli także najbliżsi współpracownicy W. Stysia, jego asystenci Z. Banaszewski i J. Nadwyczański ${ }^{35}$. Natomiast S. Serwacki, po nieuzyskaniu zgody w kwietniu 1949 roku na dalsze zatrudnienie w Katedrze Ekonomii, ostatnie cztery miesiące pracował w Katedrze Nauki Skarbowości i Prawa Skarbowe-

27 Archiwum Uniwersytetu Wrocławskiego, Wydział Prawa (W. Prawno-Administracyjny do 1950 r.) W-III/0001, Rada Wydziału — protokoły posiedzeń 1950-1956, sygn. AU-271/2, s. 168.

28 E. Kundera, Zakład myśli ekonomicznej, „Przegląd Prawa i Administracji” 100/1, 2015, s. 335; T. Suleja, Uniwersytet Wrocławski w okresie centralizmu stalinowskiego 1950-1955, Wrocław 1995, s. 143.

29 Profesor historii gospodarczej, przyjaciel W. Stysia.

30 J. Popkiewicz został dopiero co absolwentem Wydziału Prawa, będąc jednym ze studentów-pionierów, którzy rozpoczęli naukę na Wydziale w roku akademickim 1945/1946; J. Koredczuk, Słowo wstępne, s. 8.

31 T. Suleja, op. cit., s. 189.

32 IPN Wr 120/1, Kserokopie akt osobowych profesorów Uniwersytetu Wrocławskiego po 1945 roku, s. 401, 409.

33 E. Kowalczyk, Poglądy ekonomiczne i polityczne Wincentego Stysia, Wrocław 2013, s. 137.

34 J. Chumiński, Wyższa Szkoła Ekonomiczna we Wrocławiu (1950-1974), [w:] Księga 60-lecia Akademii Ekonomicznej im. Oskara Langego we Wrocławiu, red. J. Chumiński, Wrocław 2007, s. 93.

35 T. Suleja, loc. cit.

Prawo 328, 2019

(C) for this edition by CNS 
go, kierowanej przez prof. Lesława Adama. W ramach weryfikacji profesury na Uniwersytecie został jednak ostatecznie zwolniony z dniem 31 lipca 1949 roku $^{36}$.

Po zawieszeniu W. Stysia opiekę nad zajęciami i asystentami przejściowo sprawowali J. Popkiewicz i Adolf Haber ${ }^{37}$. Powierzono ją im, ponieważ byli członkami partii i głosili „bardziej słuszne” poglądy niż prof. W. Styś. Ciekawą postacią był A. Haber, który ledwo co w 1948 roku ukończył studia (a który wcześniej był II sekretarzem Komitetu Miejskiego PPR we Wrocławiu) i mimo to powierzono mu wykłady z ekonomii politycznej, uruchomione na polecenie ministerstwa ${ }^{38}$. Objął on etat asystencki obsadzany przez ministerstwo, będąc praktycznie niezależnym od kierownictwa Katedry. Czyniło to sytuację do tego stopnia kuriozalną, że prof. W. Styś musiał pytać Radę Wydziału (posiedzenie z dnia 3 października 1951 roku), czy ma egzaminować studentów z ekonomii, a dziekan I. Jaworski z kolei pytał mgr. A. Habera, czy jest mu potrzebna pomoc w egzaminowaniu, czy nie ${ }^{39}$.

Nie do końca wiedząc, czym jest socjalistyczna ekonomia polityczna, doktoranci Katedry wybierali tematy z zakresu historii gospodarczej, a nawet zwykłej historii bądź tematyki okołoekonomicznej. Przykładowo J. Popkiewicz doktoryzował się na podstawie pracy pt. Polskie szkolnictwo średnie na Ślasku Opolskim, Teodor Nagórski — Porty wschodniego Battyku w okresie dwudziestolecia, a K. Jeżowski — Rozwój przemysłu dolnoślaskiego na tle budżetów terenowych ${ }^{40}$.

Warto przy okazji dodać, że niektórzy pracownicy Katedry Ekonomii Politycznej (zatrudnieni po 1950 roku) prowadzili także zajęcia z marksizmu, co powodowało, że sprawa obsady personalnej Katedry nabierała charakteru politycznego. Jedynym plusem było to, że łatwiej uzyskiwała ona dodatkowe etaty niż pozostałe katedry na Wydziale. Przykładowo w lutym 1953 roku ministerstwo przyznało pięć etatów dla pomocniczych pracowników nauki w Katedrze (z czego dwa były już obsadzone). Pracownicy wykładający przedmioty ideologicz-

36 Archiwum Uniwersytetu Wrocławskiego, Wydział Prawno-Administracyjny W-III/0001, Rada Wydziału — protokoły posiedzeń 1946-1949, sygn. AU-271/1, s. 105; J. Koredczuk, K. Koreń, Stanisław Serwacki (1908-1985), [w:] Pamięci zmartych Profesorów i Docentów Wydziatu Prawa, Administracji i Ekonomii Uniwersytetu Wrocławskiego 1945-2010, red. L. Lehmann, M. Maciejewski, Wrocław 2010, s. 251. Rozpoczęta wówczas weryfikacja, a w zasadzie „segregacja” uczonych miała miejsce na wszystkich wyższych uczelniach. W zależności od tego, czy pracownik naukowy został zaliczony do kategorii profesorów partyjnych, tak zwanych deklarujących się, ,wymagających izolacji” bądź stojących na pozycjach ,nacjonalistycznych i zachodnich”, uzależnione były jego szanse na karierę zawodową albo nawet możliwość zachowania pracy; P. Hübner, Polityka naukowa w Polsce w latach 1944-1953. Geneza systemu, t. 2, Wrocław-Warszawa-Kraków 1992, s. 552-553.

37 T. Suleja, op. cit., s. 143.

38 J. Chumiński, Wyższa Szkoła Handlowa we Wrocławiu (1947-1950), [w:] Księga 60-lecia Akademii Ekonomicznej im. Oskara Langego we Wrocławiu, s. 69.

39 Archiwum Uniwersytetu Wrocławskiego, Wydział Prawa (W. Prawno-Administracyjny do 1950 r.) W-III/0001, Rada Wydziału — protokoły posiedzeń 1950-1956, sygn. AU-271/2, s. 69, $114,118$.

40 Ibidem, s. 33, 42, 96. 
no-polityczne mieli także zajęcia na innych wydziałach Uniwersytetu Wrocławskiego oraz prowadzili punkty konsultacyjne z marksizmu i ekonomii w domach akademickich. Katedra Ekonomii jako katedra ideologiczna sprawowała nadzór nad organizacją i zajęciami w zakresie ekonomii na całym Uniwersytecie. Prowadzenie zajęć z ekonomii i marksizmu powodowało, że studenci z innych wydziałów korzystali z lokali Katedry Ekonomii na Wydziale Prawa, czyniąc sytuację z powodu ciasnoty lokalowej niezwykle trudną ${ }^{41}$.

Kierownictwo Katedry po W. Stysiu, od 1 kwietnia 1954 roku, objął dr Józef Kielski. By pokazać, jakże nisko upadła w tym momencie nauka ekonomii politycznej na Wydziale Prawa, warto podać kilka informacji o osobie J. Kielskiego. Przed przybyciem do Wrocławia był on aspirantem w Katedrze Ekonomii Politycznej w Instytucie Kształcenia Kadr Naukowych przy KC PZPR, kuźni marskistowskiej ekonomii politycznej, i z niej został skierowany do Wrocławia. Wcześniej, zanim został aspirantem, pracował w KW PZPR w Warszawie. Mimo zaledwie średniego wykształcenia oraz ukończenia rocznej szkoły partyjnej w Łodzi został kandydatem nauk w Instytucie ${ }^{42}$. Stopień kandydata nauk uzyskał w czerwcu 1954 roku na podstawie pracy Penetracja obcego kapitału $w$ Polsce $w$ latach międzywojennych (ze szczególnym uwzględnieniem przemystu elektroenergetycznego), miażdżącą recenzję tej pracy przed jej zatwierdzeniem przez Centralną Komisję Kwalifikacyjną dla Pracowników Naukowych przedstawił prof. Edward Lipiński. Nie na wiele to się zdało. Został kandydatem nauk, gdyż popierał go działacz partyjny Józef Zawadzki (członek Rady Naukowej przy Ministrze Oświaty). Jako kandydat nauk został skierowany do Wrocławia, gdzie objął nie tylko Katedrę Ekonomii Politycznej na Wydziale Prawa Uniwersytetu Wrocławskiego, ale także w Wyższej Szkoły Ekonomicznej we Wrocławiu. W październiku 1954 roku został zastępcą profesora, w 1955 roku prorektorem do spraw nauki Wyższej Szkoły Ekonomicznej, a w listopadzie 1956 roku docentem. Jego niezwykłą karierę naukową przerwały wydarzenia października 1956 roku, po których w listopadzie 1956 roku zrezygnował z kierownictwa Katedrą, a w kwietniu 1957 roku wyjechał do Izraela ${ }^{43}$.

Odejście prof. W. Stysia spowodowało, że nie było nikogo, kto mógłby sprawować opiekę naukową nad młodymi pracownikami Katedry oraz uniemożliwiało wszczęcie przez nich przewodów kandydackich ${ }^{44}$. Powrót prof. W. Stysia do

41 Ibidem, s. 130, 180, 250, 281.

42 B. Czarny, Wpływ aspirantów Katedry Ekonomii Politycznej w Instytucie Kształcenia Kadr Naukowych w Warszawie na polska ekonomie po II wojnie światowej, „Ekonomia” 2015, nr 41, s. 33, 39, przyp. 35.

43 J. Chumiński, Wyższa Szkoła Ekonomiczna we Wrocławiu (1950-1974), s. 89-90.

44 Archiwum Uniwersytetu Wrocławskiego, Wydział Prawa (W. Prawno-Administracyjny do 1950 r.), W-III/0001, Rada Wydziału — protokoły posiedzeń 1950-1956, sygn. AU-271/2, s. 271. 
Katedry był możliwy dopiero po zmianach w Polsce w 1956 roku $^{45}$. W okresie od rezygnacji z kierownictwa Katedry przez J. Kielskiego i objęcia jej ponownie przez W. Stysia tymczasowe jej kierownictwo powierzono R. Sorgensteinowi (sprawującemu już od odejścia $\mathrm{z}$ Katedry prof. W. Stysia funkcję organizatora Katedry), a opiekę naukową nad nią prof. A. Chełmońskiemu ${ }^{46}$.

Od początku istnienia Wydziału Prawa ważne miejsce w programie prac Katedry zajmowała także historia myśli politycznej. Była ona zarówno przedmiotem badań, jak i dydaktyki, na której potrzeby W. Styś opracował nawet skrypt z historii myśli ekonomicznej. Badania nad historią myśli ekonomicznej w Katedrze rozwinęły się w pełni dopiero po 1956 roku, kiedy to z inicjatywy W. Stysia zainicjowano badania poglądów wielkich ekonomistów: François Quesnay (W. Styś), Johna Stuarta Milla (T. Afeltowicz), Williama Nasau Seniora (Wiesław Samec$\mathrm{ki}^{47}$ ) i Antoine'a Augustina Cournota (R. Sorgenstein) ${ }^{48}$.

Należy dodać, że pracownicy Katedry wówczas w praktyce pracowali na dwóch etatach, jednym w ramach Katedry Ekonomii Politycznej na Wydziale Prawa i drugim w Wyższej Szkole Handlowej we Wrocławiu, której kadra w zasadzie opierała się na kadrze Katedry Ekonomii Uniwersytetu Wrocławskiego oraz częściowo po 1950 roku Wyższej Szkoły Ekonomicznej.

Symboliczne zakończenie najtrudniejszego okresu w dziejach Katedry Ekonomii Politycznej na Wydziale Prawa nastąpiło na posiedzeniu Rady Wydziału w dniu 27 listopada 1956 roku, na którym jednomyślnie podjęła ona uchwałę „o wystąpieniu z wnioskiem do Senatu o reaktywowanie na Katedrze Ekonomii Politycznej prof. dr Wincentego Stysia, niesłusznie skrzywdzonego i odsuniętego od pracy naukowej na wydziale prawa i mianowanie go profesorem nadzwyczajnym na Katedrze Ekonomii Politycznej Wydziału Prawa naszego Uniwersytetu"49.

\section{Bibliografia}

Archiwum Uniwersytetu Wrocławskiego, W-VIII-52, Zespoły katedr i instytutów 1950-1975.

Archiwum Uniwersytetu Wrocławskiego, Wydział Prawno-Administracyjny W-III/0001, Rada Wydziału — protokoły posiedzeń 1946-1949, sygn. AU-271/1.

45 E. Kundera, Instytut Nauk Ekonomicznych, s. 329.

46 Archiwum Uniwersytetu Wrocławskiego, Wydział Prawa W-III/0001, Rada Wydziału protokoły posiedzeń 1956-1960, sygn. AU-271/3, s. 333.

47 Zatrudniony w Katedrze od 1 stycznia 1954 roku, jako bibliotekarz, a od 1960 roku, jako pracownik naukowy.

48 E. Kundera, Zakład myśli ekonomicznej, s. 335.

49 Archiwum Uniwersytetu Wrocławskiego, Wydział Prawa W-III/0001, Rada Wydziału protokoły posiedzeń 1956-1960, sygn. AU-271/3, s. 347. 
Archiwum Uniwersytetu Wrocławskiego, Wydział Prawa (W. Prawno-Administracyjny do 1950 r.) W-III/0001, Rada Wydziału — protokoły posiedzeń 1950-1956, sygn. AU-271/2.

Archiwum Uniwersytetu Wrocławskiego, Wydział Prawa W-III/0001, Rada Wydziału — protokoły posiedzeń 1956-1960, sygn. AU-271/3.

IPN Wr 120/1, Kserokopie akt osobowych profesorów Uniwersytetu Wrocławskiego po 1945 roku.

A.K., Adw. dr Zygmunt Banaszewski [wspomnienia pośmiertne], „Palestra” 31, 1987, nr 6.

Chumiński J., Wyższa Szkoła Ekonomiczna we Wrocławiu (1950-1974), [w:] Księga 60-lecia Akademii Ekonomicznej im. Oskara Langego we Wrocławiu, red. J. Chumiński, Wrocław 2007.

Chumiński J., Wyższa Szkoła Handlowa we Wrocławiu (1947-1950), [w:] Księga 60-lecia Akademii Ekonomicznej im. Oskara Langego we Wrocławiu, red. J. Chumiński, Wrocław 2007.

Czarny B., Wpływ aspirantów Katedry Ekonomii Politycznej w Instytucie Kształcenia Kadr Naukowych w Warszawie na polska ekonomię po II wojnie światowej, „Ekonomia” 2015, nr 41, s. $25-57$.

Hübner P., Polityka naukowa w Polsce w latach 1944-1953. Geneza systemu, t. 2, Wrocław-Warszawa-Kraków 1992.

Koredczuk J., 60-lecie powolania katedr historyczno-prawnych na Wydziale Prawa Uniwersytetu Wrocławskiego, „Prawo” 303, 2007, s. 9-73.

Koredczuk J., Słowo wstępne, [w:] Wydział Prawa, Administracji i Ekonomii Uniwersytetu Wrocławskiego w fotografiach (1945-2010), oprac. L. Lehmann, Wrocław 2010.

Koredczuk J., Koreń K., Stanisław Serwacki (1908-1985), [w:] Pamięci zmartych Profesorów i Docentów Wydziału Prawa, Administracji i Ekonomii Uniwersytetu Wrocławskiego 1945-2010, red. L. Lehmann, M. Maciejewski, Wrocław 2010.

Kowalczyk E., Poglądy ekonomiczne i polityczne Wincentego Stysia, Wrocław 2013.

Kundera E., Instytut Nauk Ekonomicznych, „Przegląd Prawa i Administracji” 100/1, 2015, s. 329-333. Kundera E., Zakład myśli ekonomicznej, „Przegląd Prawa i Administracji” 100/1, 2015.

Kuta T., Moje wspomnienia, „Studia i Materiały z Dziejów Uniwersytetu Wrocławskiego” 2, 1993. Olszewski L., Droga życiowa, „Ekonomia” 2018, nr 18.

Ryszka F., Pamiętnik inteligenta. Samo życie, Łódź 1996.

Sielezin J.R., Działania UB wobec kadry naukowej Uniwersytetu Wrocławskiego w 1950 roku, „Śląski Kwartalnik Historyczny Sobótka” 63, 2008, nr 1.

Spis wykładów w roku akademickim 1945/46, Wrocław 1946.

Spis wykładów w roku akademickim 1947/8, Wrocław 1947.

Spis wykładów w roku akademickim 1948/9, Wrocław 1948.

Spis wykładów w roku akademickim 1949/50, Wrocław 1949.

Suleja T., Uniwersytet Wrocławski w okresie centralizmu stalinowskiego 1950-1955, Wrocław 1995.

Wrzesiński W., Uniwersytet Wrocławski 1945-1995, Wrocław 1995.

\section{The history of the Department of Political Economy at the Faculty of Law, University of Wrocław in 1945-1956}

\section{Summary}

The Department of Political Economy at the Faculty of Law, University of Wrocław, went through an extremely important and turbulent period in 1945-1956. It was a time of building the Department and of its scholarly development. The main role in the Department was played by Professor Wincenty Styś, almost from the very beginning persecuted by the communist authorities. A characteristic feature of the Department were frequent changes of auxiliary academic staff. In addition to lectures on political 
economy and economic history, the academics working at the Department also lectured on ideological subjects (Marxism), both at the Faculty of Law and other faculties at the University of Wrocław. That is why the Department was more politicised and the authorities interfered in its work more often than in the case of other departments. Most staff, in addition to working at the Department, were also employed at the School of Business and then School of Economics in Wrocław.

Keywords: political economy, Department of Political Economy, ideological-political subjects, University of Wrocław, Wincenty Styś, Faculty of Law

\section{Die Geschichte des Lehrstuhls für Politische Ökonomie an der Fakultät für Recht der Universität Wrocław in den Jahren 1945-1956}

\section{Zusammenfassung}

Die Jahre 1945-1956 stellten für den Lehrstuhl für Politische Ökonomie an der Fakultät für Recht der Universität Wrocław eine wichtige und bewegte Zeit dar. Das war die Zeit seiner Gestaltung und wissenschaftlichen Entwicklung. Die führende Rolle an dem Lehrstuhl spielte Professor Wincenty Styś, fast von Anfang an verfolgt durch die kommunistischen Behörden. Für den Lehrstuhl war charakteristisch, dass seine wissenschaftlichen Hilfsmitarbeiter oft wechselten. Neben den Vorlesungen zur politischen Ökonomie und Wirtschaftsgeschichte lehrten die Mitarbeiter des Lehrstuhls auch ideologische Fächer sowohl an der Fakultät für Recht als auch an den anderen Fakultäten der Universität Wrocław. Aus diesen Gründen unterlag der Lehrstuhl größerer politischer Abhängigkeit und Einmischung der Behörden. Die Mehrheit der Mitarbeiter des Lehrstuhls war auch an der Handelsakademie [Wyższa Szkoła Handlowa] und später auch an der Hochschule für Wirtschaft [Wyższa Szkoła Ekonomiczna] in Wrocław tätig.

Schlüsselworte: politische Ökonomie, Lehrstuhl für Politische Ökonomie, ideologisch-politische Fächer, Universität Wrocław, Wincenty Styś, Fakultät für Recht 